\title{
顎補経患者の統計的調査とその義霜の経過観察
}

第 1 報 調查方法と被験者の概要

東田 佑巟 細谷 仁憲 根本一男

\section{A Clinical Survey of Maxillofacial Prosthetic}

Part 1. Material and Method

\author{
Yuji Higashida, Yoshinori Hosoya, Kazuo Nemoto
}

\section{I. 緒言}

顎の実質欠損を有する顎補緅患者にとっては, 一般有 床義蒾装着の目的である形態的, 機能的障害の他に精神 的障害が加わり, その頻補緅物（口蓋補緅・顔面補緅を 含む，以下同じ）の装着後の経過は通常あまり良好とは いえない.

従来より䅡補綴の研究報告はかなり多いが, その大部 分は症例についてその技術的困難さを克服した報告であ った. したがって頻補緅物の多数例について, 総括的に 経過観察し，颚補緅物による機能および形態的な回復状 態と精神的な回復状態を観察した報告は殆んど見られな (1).

我々は䪽補綴物の装着によって起こる審美性の問題, 生理的機能の回復の問題, 残存する組織保護の問題, ま た顎補緅物装着前後の社会復帰の問題について何等かの 知見を得るため, 顶補緅物装着者についての統計的調査 と顎補緅物装着後の経過観察を行ったので, 第 1 報とし て調查方法と被験者の概要について報告する.

\section{II. 調查資料および調查方法}

調查対象は炤和 42 年 10 月より昭和 50 年 4 月までの 7 年半の間に東北大学歯学部附属病院補綴科において製 作した 109 個の䪽補緅物であり，患者数は 90 名である。

調查は昭和 49 年 11 月より昭和 50 年 8 月まで行った.

東北大学歯学部蒾科補緅学第 2 講座 (主任 : 根本一男教授)

Second Deparment of Prosthetic Dentistry, School of Dentistry, Tohoku University (Chief : Prof. Kazuo Nemoto)

昭和 53 年 8 月 30 日受付
まず対象となる症例に対して1通ずつ往復はがきを用意 し，顎補緅物使用者に限らず，不使用症例者についても 経過観察の為に来院することを勧めるとともに顎補緅物 の使用状態に関するアンケートに回答を求めた.

来院した被験者には顎補緅物装着時のカルテおよびプ ロトコールと被験者により返信されたアンケート回答を 対比し，顎補緅物装着後の変化を評価した.

診査はあらかじめ判定基準について詳細に打ち合せを 行い, 評価をできるだけばらつきのないようにつとめ た. はじめに現在の義齿に対する使用状況について診查 用紙を用いて問診および視診, 聴診を行い，返信された アンケートの回答と比較検討を行った. さらに適合性, 安定性, 咀礵能率, 発音, 義歯の清掃状態, 義歯の破損 状態, 鈎歯の他緩動摇, 審美性の回復状態, 顎義歯装着 後の再発の有無について, 久損周囲粘膜の状態, 開口度 の回復状態, 過去における影補緅の経験, その他口腔内 所見の特記事項と患者の希望事項について診査した.

適合性と安定性について判定基準の均一化をはかるた め良, 可, 不良とに分け, 良は義歯の維持安定が認めら れそのまま義歯として使用に耐えるもので, 改床, 修理 を必要としないものとした，可は維持安定があまり良く ないが使用に耐えるものとした，不良は義歯の維持安定 が不良で改床，修理さらに再製作が必要であると認めら れたものである.

咀嚼能率としてパン, カマボコ,きゅうり, 八ム、ビ やがいも，キャべッ，たくわん，せんべい，あめ，する め, ピーナッッ, りんごの各食品について, 可能か不可 能かまた日常食べているか, 経験がないかで判断した。 その他よく食べられる食品、食べられない食品について む問診により調查した。

発音に関して簡単な言菄「サクラがサイタ」を発音さ 
せるとともに，問診の日常的な会話の明瞭度の両者から 赔話についての障害があるかどうかを判断した。

義歯の清掃状態については義歯の蒾垢及び歯石の有無 で良，可，不良を判定し，義歯の管理として食後かなら ず清掃するのを良, 1〜2 回/1 日清掃するのを可, ほと んど清掃しないのを不良とした. 義菌の破損状態として 回数, 部位, 年月日とその原因について調査した.

鈎歯の弛緩動摇について歯冠をピンセットで動かし, 人差し指の腹を歯頙部にあてて触診し動摇の程度を $\mathrm{m}_{0} \sim \mathrm{m}_{3}$ までに分類して診查した. 動摇度は歯の動摇が ほとんど認められないものを $\mathrm{m}_{0}$ とし, 唇舌的に動摇が ある場合を $\mathrm{m}_{1}$ とし, さらに近遠心方向にも動摇が認め られるものを $\mathrm{m}_{2}$ とした. それから唇舌方向, 近遠心方 向のほかに垂直方向にも動摇するものを $\mathrm{m}_{3}$ とした.

審美性については問診により義歯装着前後の状態を比 較して, 良くなっているのを良, 変わらないのを可, 悪 くなったのを不可とし, 視診により気ついた点, 例えば 非対称性があるかどうか, 顔面に欠損があるかどうかに ついて診查した.

その他義歯装着後の再発の有無, 久損周囲の粘膜の状 態に問題があるかないか，あるとすればどういう状態か についても診査した.

また過去における顎補緅の経験のある患者については その個数, 各々の再製作の理由, 各々の装着期間につい て診査し，使用を中止した理由と時期と問題点が出て来 た時期もいっしょに診查した.

以上各診査項目の他にこれからの颓補緅物の指針とし て患者が何を希望するのかも合せて診査した.

\section{III. 被験者の概要}

䫑補緅物の使用状態に関するアンケートの回答率は図 1 で，義歯装着者 90 名中 65 名 $(72.2 \%)$ が回答を寄せ た. 死亡 20 名 $(22.2 \%)$, 未返信者 2 名 $(2.2 \%)$, 住所 不明者 3 名 (3.3\%) であった. アンケートに返信を寄 せた被験者のうち診査に応したのは 52 名 (57.8\%) で あった.

次に調查期間内の患者数と補緅症例数の推移をあらわ したのが図 2 である. 昭和 42 年 10 月より昭和 50 年 4 月までに東北大学歯学部附属病院補緅科に来院した被験 者 97 名，その内顎義菌装着者数 90 名，再製作の為来院 した患者数 25 名でその内㴿義歯装着者数 19 個合計 109 症例数である. 昭和 44 年頃より来院者が増え始め, 昭 和 45 年頃より再製作のために患者が再び補経科に来院

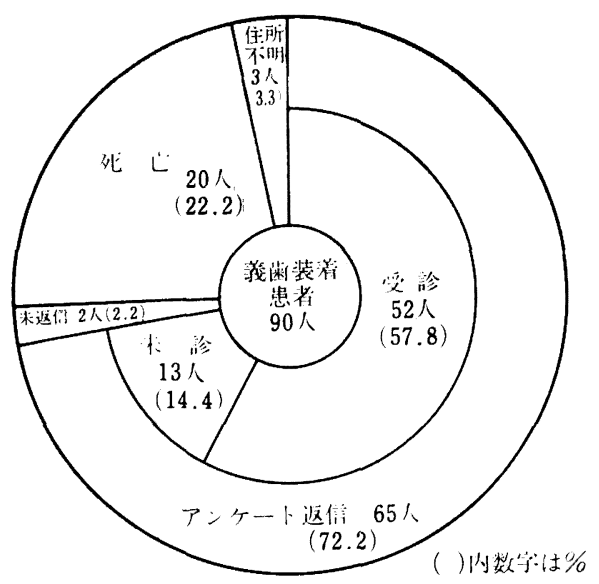

図 1 受診率と返信率

し始めているのがわかる. 最も多くの被験者が来院した のは昭和 48 年の 22 名, 最も多かった顎補緅の装着数は 昭和 45 年の 19 症例である.

次に補緅処置患者数および返信者数と受診者数をそれ ぞれ男女, 年齢, 職業, 上下䫑, 主訴, 診断, 治療内容, 残存歯数，対合歯，歯牙欠損様式 (部分床義歯について は中沢式分類)，顎欠損様式，手術から装着までの期間， 使用期間，義歯使用経験の有無について被験者の分布状 態を比較してみた。

表 1 は男女にわけた被験者数であるが，頻義歯の経過 観察について調查しえたのは対象全体でなくアンケート については $72.2 \%$ であり，受診者ではさらに少なく $57.8 \%$ であった. したがってもしアンケートないし受診 者に応じた症例が調查対象のうちあるかたよりをもった 症例であるとすれば，調查結果をそのまま信頼できなく なる. そこでこの点について検討を加えた. 調査対象全 体の男性と女性の百分率は男性 $65.5 \%$ ，女性 $34.5 \%$ で ある.これに対してアンケートに返信を寄せた症例者群 では男性 $66.2 \%$ ，女性 $33.8 \%$ であった。 また診查を受 けた症例者群では男性 $67.3 \%$ ，女性 $32.7 \%$ である. 対 象全体に扔ける返信者群および受診者群においてもほと んど変化していないように見える.この判定の基準とし てカイ平方を使って $5 \%$ の危険率で検定すると返信者群 の場合にはカイ平方は $X^{2}=0.011$ であり, 受診者群に ついては $X^{2}=0.069$ であるから両者とも有意差はなく 調查対象全体の比率と差異がないと判定した.

図 3 は年齢別にみた被験者数の分布である. 補緅処直 患者において 60 69歳が 27 名 (30.0\%) で最も多く, 次いで 50〜59歳が 22 名 (24.4\%) と続いている. アン 


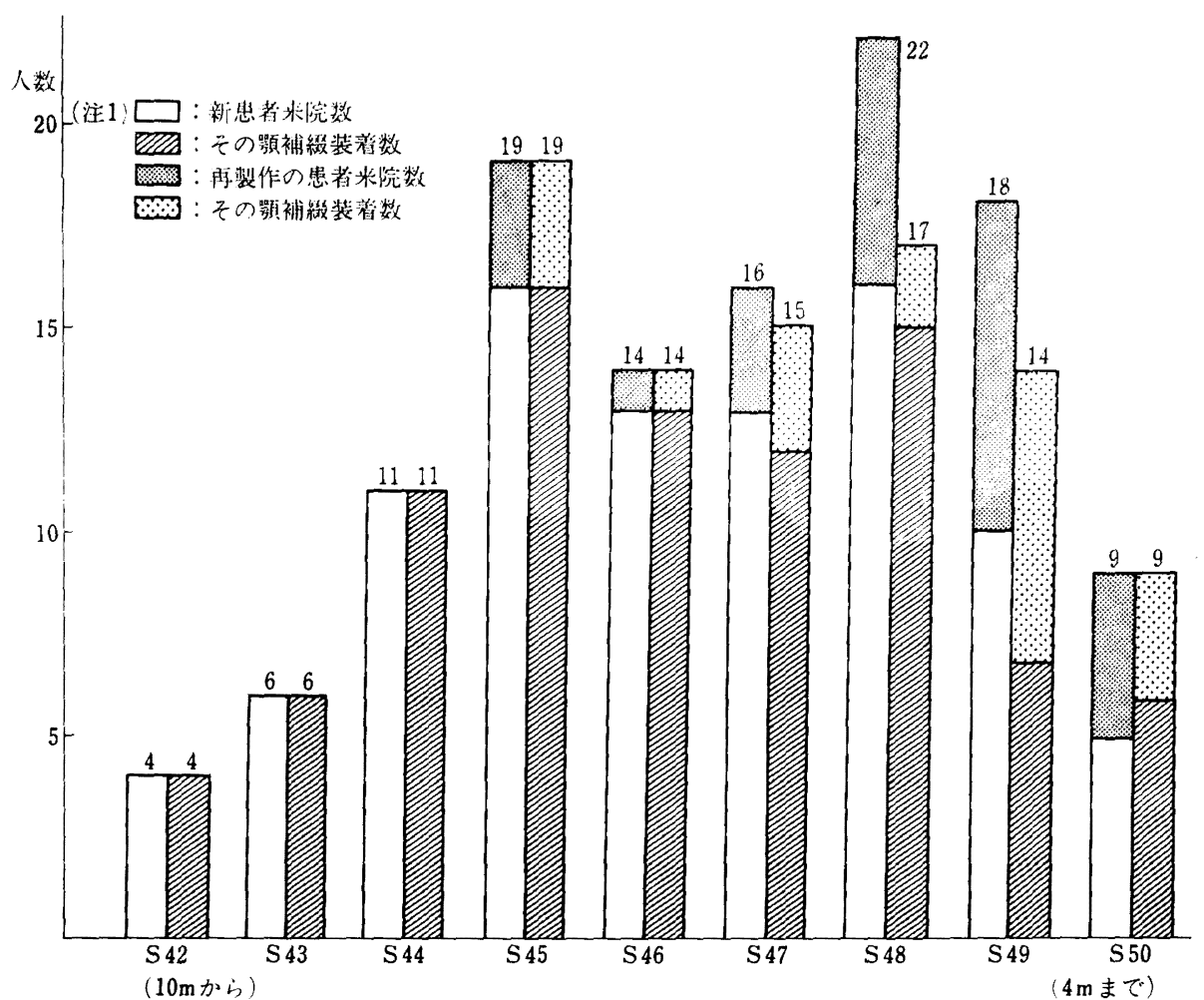

図 2 各年別にみた患者数と補緅数

表 1 男女別にみた被験者数

\begin{tabular}{|c|c|c|c|c|c|c|c|}
\hline & & 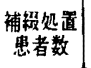 & 計 & $\begin{array}{ll}\text { 返 } & \text { 信 } \\
\text { 著数 }\end{array}$ & 計 & $\mid \begin{array}{ll}\text { 舜 } & \text { 診 } \\
\text { 数 }\end{array}$ & 計 \\
\hline \multirow{2}{*}{ 男 } & 上頻 & $\begin{array}{c}55 \\
(61.1)\end{array}$ & \multirow{2}{*}{$\begin{array}{c}59 \\
(65.5)\end{array}$} & $\begin{array}{c}39 \\
(60.0)\end{array}$ & \multirow{2}{*}{$\begin{array}{c}43 \\
(66.2)\end{array}$} & $\begin{array}{c}34 \\
(65.4)\end{array}$ & \multirow{2}{*}{$\begin{array}{c}35 \\
(67.3)\end{array}$} \\
\hline & 下 頻 & $\begin{array}{c}4 \\
(4.4)\end{array}$ & & $\begin{array}{c}4 \\
(6.2) \\
\end{array}$ & & $\begin{array}{c}1 \\
(1.9) \\
\end{array}$ & \\
\hline \multirow{3}{*}{ 女 } & 上影 & $\begin{array}{c}29 \\
(32.2)\end{array}$ & \multirow{2}{*}{$\begin{array}{c}31 \\
(34.5)\end{array}$} & $\begin{array}{c}20 \\
(30.8)\end{array}$ & \multirow{2}{*}{$\begin{array}{c}22 \\
(33.8)\end{array}$} & $\begin{array}{c}16 \\
(30.8) \\
\end{array}$ & \multirow{2}{*}{$\begin{array}{c}17 \\
(32.7)\end{array}$} \\
\hline & 下 䝷 & $\begin{array}{c}2 \\
(2.2)\end{array}$ & & $\stackrel{2}{(3.1)}$ & & $\begin{array}{c}1 \\
(1.9)\end{array}$ & \\
\hline & & $\begin{array}{c}90 \\
(100.0)\end{array}$ & & $\begin{array}{c}65 \\
(100.0)\end{array}$ & & $\begin{array}{c}52 \\
(1000.0)\end{array}$ & \\
\hline
\end{tabular}

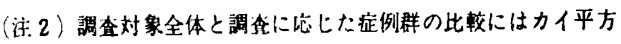
を使った。

判定の基準は. $5 \%$ 水準であり、有意差が認められた場合 には星印を付けた。

返信者群: $\mathrm{x}^{2}=0.011$

受診者群 : $\mathrm{x}^{2}=0.009$

ケート返信者では同しように 60〜69歳が18名(26.9 $\%)$, 次いで 50〜59歳が 17 名 (26.2\%) と続いている. 受診した中でも 60 ～69 歳が 14 名（26.9\%）で最も多

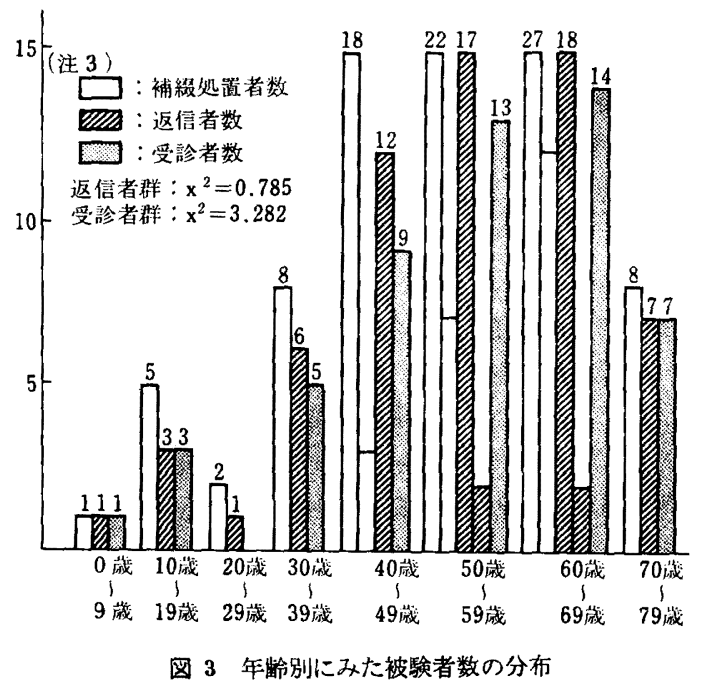

く, 次いで 50〜59歳が 13 名 (25.0\%) と調查対象全体 における年龄別の比率は返信者および受診者においても ほとんど変化は認められなかった.

図 4 は職業別にみた被験者数の分布である. 図に示さ 


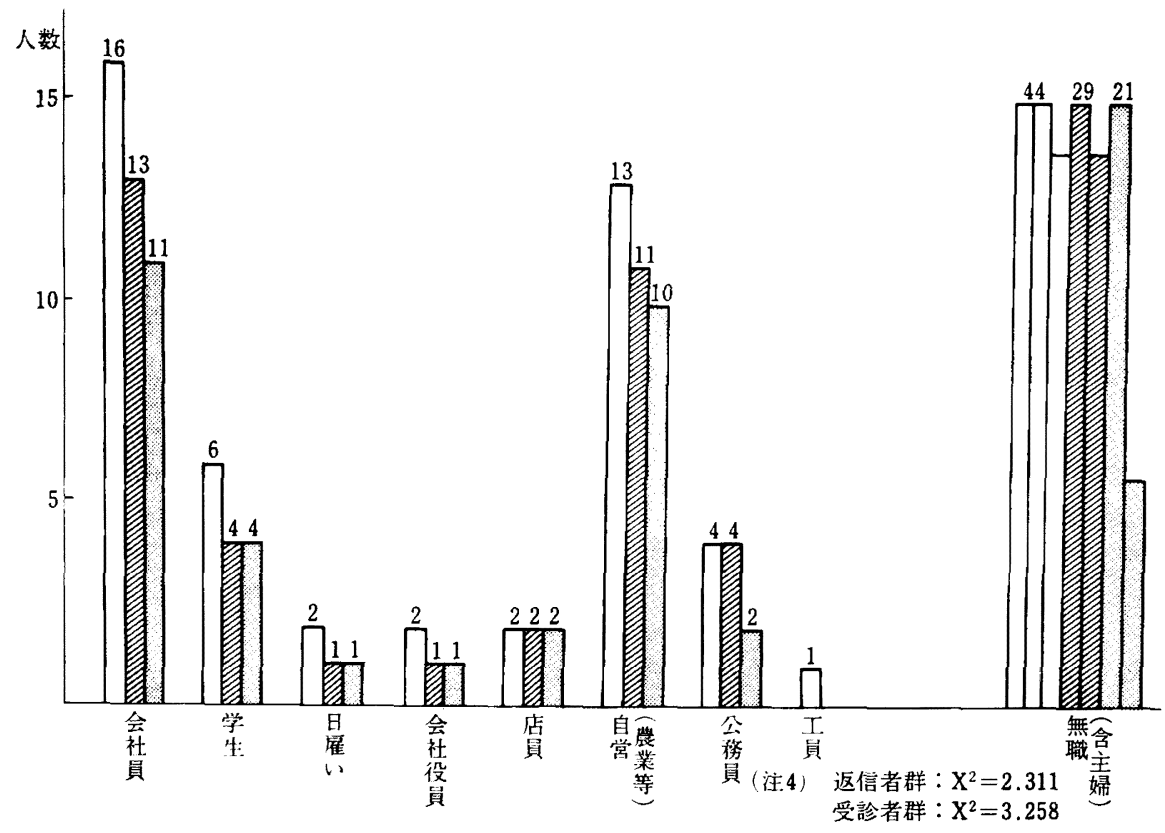

図 4 職業別にみた被験者数の分布

表 2 上下額別にみた被験者数

\begin{tabular}{|c|c|c|c|c|}
\hline \multicolumn{2}{|c|}{ 上下䫑 } & 補絠処置患者数 & 返信者数 & 受參者数 \\
\hline 上 & 後 & $\begin{array}{c}80 \\
(88.9)\end{array}$ & $\begin{array}{c}55 \\
(84.6)\end{array}$ & $\begin{array}{c}47 \\
(90.4)\end{array}$ \\
\hline 頻 & $\begin{array}{l}\text { 先 } \\
\text { 性 } \\
\text { 列 }\end{array}$ & $\begin{array}{c}4 \\
(4.4) \\
\end{array}$ & $\begin{array}{c}4 \\
(6.2) \\
\end{array}$ & $\begin{array}{c}3 \\
(5.8) \\
\end{array}$ \\
\hline 下 & 頻 & $\begin{array}{c}6 \\
(6.7)\end{array}$ & $\begin{array}{c}6 \\
(9.2)\end{array}$ & $\begin{array}{c}2 \\
(3.8)\end{array}$ \\
\hline & it & $\begin{array}{c}90 \\
(100.0)\end{array}$ & $\begin{array}{c}65 \\
(100.0)\end{array}$ & $\begin{array}{c}52 \\
(100.0)\end{array}$ \\
\hline
\end{tabular}

（注 5 ）返保者群: $\mathrm{X}^{2}=0.720$

受禞者样: $\mathrm{X}^{2}=0.689$

れる通り，無職（主婦を含む）が調査対象, 返信者, 受 診者のすべてに最も多く，44名 (44.6\%)，29名 (40.4 \%), 21 名 (48.9\%) となっている. 次いで会社員が多 く 16 名 $(20.2 \%), 13$ 名 $(21.2 \%), 11$ 名 $(17.8 \%)$ と なっている．以下は自営業（農業を含む）が 13 名（16.9 $\%), 11$ 名 (19.2\%), 10 名 (14.4\%) となっており, 対象全体における職業別の比率は返信者および受診者に おいても変化は認められなかった.

表 2 は上下顎別にみた被験者数である. 調查対象にお いて上䫑は 84 名 $(93.3 \%)$ ，下䫑は 6 名 $(6.7 \%)$ であ
った. これに対してアンケート返信者では上頻 59 名 (90.8\%), 下顎 6 名 $(9.2 \%)$ であり, 受診者では上額 50 名 $(96.2 \%)$, 下䫟 2 名 (3.8\%) であった. 対象全体

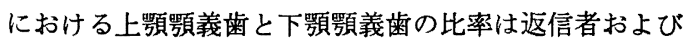
受診者においてほとんど変化は認められなかった。

図 5 は主訴別にみた被験者数の分布である. 補緅処置

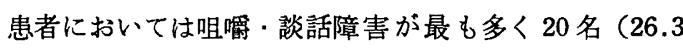
$\%)$, 次いで咀獣障害 18 名 (23.7\%), 談話障害 14 名 (18.4\%) となっており, 返信者では咀徱・談話障害と 咀啷障害が 17 名 (27.0\%), 次いで䚿話障害 11 名 (17.4 \%)となっていた．受診者では咀喂・談話障害と咀礵障 害が 15 名 (27.2\%) と最も多く, 次いで談話障害 8 名 （15.4\%）と続いていた．咀㗖障害と咀覆・㛙話障害の 主訴が最も多かった. 主訴別の比率は返信者および受診 者においても有意な差はなかった。

表 3 は診断別にみた被験者数である. 調查対象では腫

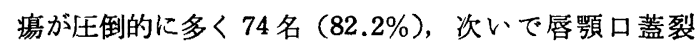
4 名 (4.4\%) となっている. 返信者では腫瘍が 57 名 $(87.8 \%)$ ，唇頇口蓋裂 4 名 $(6.2 \%)$ となっている. 受 診者において腫瘍が 43 名 (82.7\%)，唇頻口蓋裂 3 名 (5.8\%) であった. 診断別の比率においては返信者およ び受診者においてもほとんど変化は認められなかった.

表 4 は治療内容別にみた被験者数である. 調査対象に おいては手術と放射線療法を受けた者が 68 名（81.9\%） 


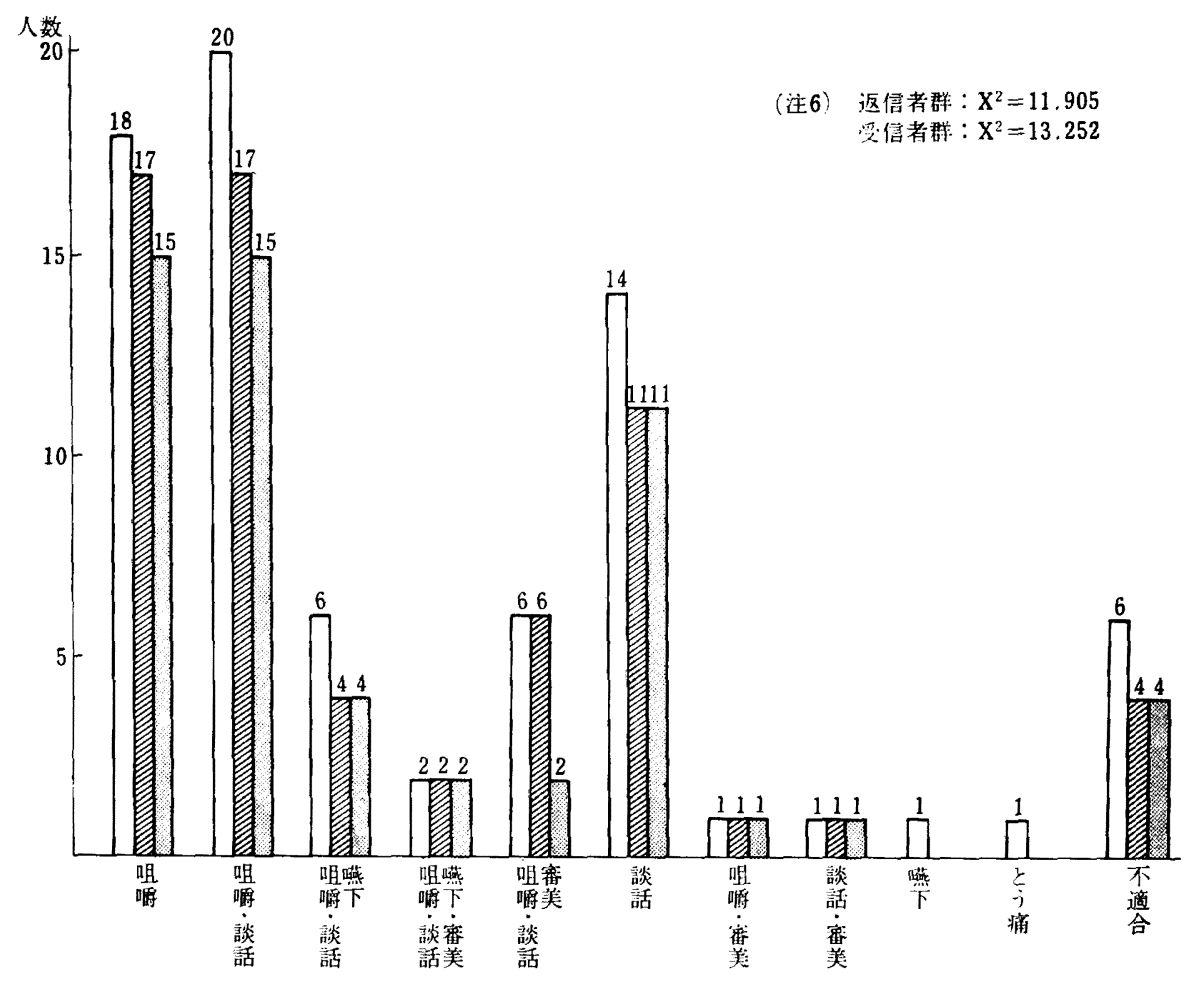

図 5 主訴別にみた被験者数の分布

表 3 診断別にみた被験者数

\begin{tabular}{|c|c|c|c|c|}
\hline 䒠 & & $\begin{array}{l}\text { 補緅処置患 } \\
\text { 老数 }\end{array}$ & 返信者数 & 受參者数 \\
\hline \multirow{2}{*}{ 腫瘍 } & 上頻 & $\begin{array}{c}74 \\
(82.2) \\
\end{array}$ & $\begin{array}{c}51 \\
(78.5) \\
\end{array}$ & $\begin{array}{c}43 \\
(82.7) \\
\end{array}$ \\
\hline & 下顎 & $\begin{array}{c}6 \\
(6.6)\end{array}$ & $\begin{array}{c}6 \\
(9.3)\end{array}$ & $\begin{array}{c}2 \\
(3.8)\end{array}$ \\
\hline 硬口蓋腿揘 & 上顎 & $\begin{array}{c}1 \\
(1.1) \\
\end{array}$ & $\begin{array}{c}1 \\
(1.5)\end{array}$ & $\begin{array}{c}1 \\
(1.9) \\
\end{array}$ \\
\hline 術后性煩部胧胞 & 上鶜 & $\left(\begin{array}{c}1 \\
(1.1)\end{array}\right.$ & $\left(\begin{array}{c}1 \\
(1.5)\end{array}\right.$ & $\begin{array}{c}1 \\
(1.9) \\
\end{array}$ \\
\hline 骨 & 1:别 & $\left(\begin{array}{c}1 \\
(1.1\end{array}\right)$ & $\begin{array}{c}1 \\
(1.5)\end{array}$ & $\begin{array}{c}1 \\
(1.9)\end{array}$ \\
\hline W.Christian 独 & 1:韻 & $\begin{array}{c}1 \\
(1.1) \\
\end{array}$ & $\begin{array}{c}0 \\
(0.0) \\
\end{array}$ & $\begin{array}{c}0 \\
(0.0) \\
\end{array}$ \\
\hline 聋顎口蓋垒 & 上㓵 & $\begin{array}{r}4 \\
(4.4) \\
\end{array}$ & $\begin{array}{c}4 \\
(6.2) \\
\end{array}$ & $\begin{array}{c}3 \\
(5.8) \\
\end{array}$ \\
\hline 不 & 上䫟 & $\begin{array}{c}2 \\
(2.2) \\
\end{array}$ & $\begin{array}{c}1 \\
(1.5) \\
\end{array}$ & $\begin{array}{c}1 \\
(1.9)\end{array}$ \\
\hline \multicolumn{2}{|l|}{ 椐 } & $\begin{array}{c}90 \\
(100.0)\end{array}$ & $\begin{array}{c}65 \\
(100.0)\end{array}$ & $\begin{array}{c}52 \\
(100.0)\end{array}$ \\
\hline
\end{tabular}

（注 7) 返信者群: $\mathrm{X}^{2}=1.628$

受祅者群: $\mathrm{X}^{2}=1.868$
表 4 治療内容別にみた被験者数

\begin{tabular}{|c|c|c|c|c|c|c|c|}
\hline \multirow{4}{*}{ 治療内容 } & & \multicolumn{2}{|c|}{ 補緅処置患者数 } & \multicolumn{2}{|c|}{ 返信者数 } & \multicolumn{2}{|c|}{ 受郝者数 } \\
\hline & 上䪷 & $(8.4)$ & \multirow{3}{*}{$\begin{array}{c}12 \\
(14.5)\end{array}$} & $\left(\begin{array}{c}6 \\
(9.2)\end{array}\right.$ & & $\begin{array}{c}5 \\
(9.6)\end{array}$ & \multirow{3}{*}{$(13.5)$} \\
\hline & 下 䅡 & $(2.4)$ & & 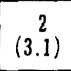 & $\left(\begin{array}{c}11 \\
(16.9)\end{array}\right.$ & $\begin{array}{c}0 \\
(0.0)\end{array}$ & \\
\hline & 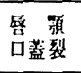 & $(3,6)$ & & $\begin{array}{c}3 \\
(4.6)\end{array}$ & & $\begin{array}{c}2 \\
(3.8) \\
\end{array}$ & \\
\hline \multirow{2}{*}{$\begin{array}{c}\text { 手術十 } \\
\text { 股射程 }\end{array}$} & 上. 頻 & $\begin{array}{c}64 \\
(4.8) \\
\end{array}$ & \multirow{2}{*}{$\left(\begin{array}{c}68 \\
(81.9)\end{array}\right.$} & $\begin{array}{c}49 \\
(75.3) \\
\end{array}$ & \multirow{2}{*}{$\begin{array}{c}53 \\
(81.5)\end{array}$} & $\begin{array}{c}42 \\
(80.8) \\
\end{array}$ & \multirow{2}{*}{$\begin{array}{c}44 \\
(84.6)\end{array}$} \\
\hline & 下弱 & $\begin{array}{r}4 \\
(4.8) \\
\end{array}$ & & $\begin{array}{r}4 \\
(6.2) \\
\end{array}$ & & $\begin{array}{c}2 \\
(3.8) \\
\end{array}$ & \\
\hline 化学撩法 & 上暍 & \multicolumn{2}{|c|}{$\stackrel{2}{(2.4)}$} & \multicolumn{2}{|c|}{$(0.0)$} & \multicolumn{2}{|c|}{$(0.0)$} \\
\hline \multirow[t]{2}{*}{ 言語治㫊 } & 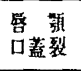 & \multicolumn{2}{|c|}{$(1.2)$} & \multicolumn{2}{|c|}{$\begin{array}{c}1 \\
(1.5)\end{array}$} & \multicolumn{2}{|c|}{ (1.9) } \\
\hline & & \multicolumn{2}{|c|}{$\begin{array}{c}83 \\
(100.0)\end{array}$} & \multicolumn{2}{|c|}{$\begin{array}{c}65 \\
(100.0)\end{array}$} & \multicolumn{2}{|c|}{$\begin{array}{c}52 \\
(100.0)\end{array}$} \\
\hline
\end{tabular}

(注 8) 返信者群 $\mathrm{X}^{2}=1.739$

受診者群 $\mathrm{X}^{2}=1.263$ 


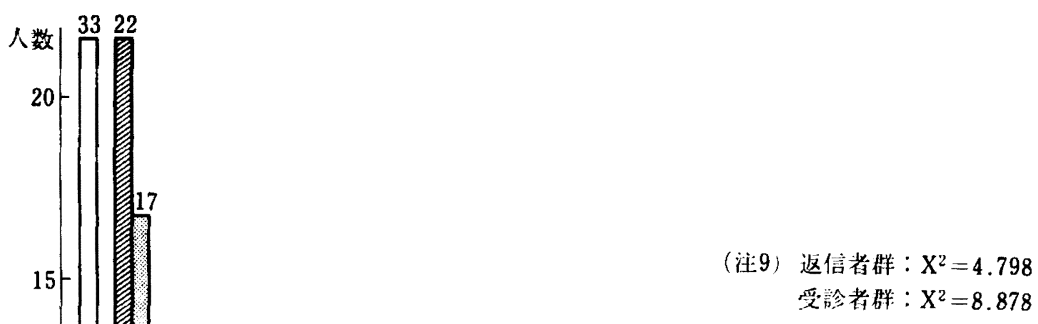

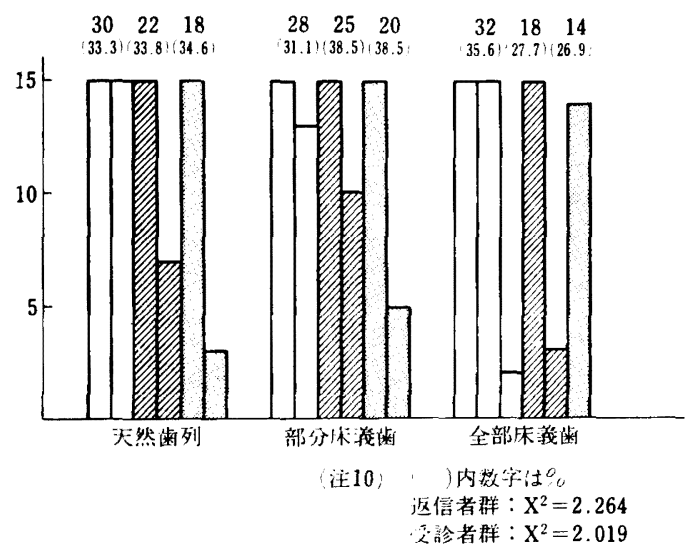

図 7 対合歯別にみた被験者数の分布

と多く，次いで手術のみが 12 名 (14.5\%) と続いてお り，返信者では手術と放射線療法を受けた者が 53 名 $(81.5 \%)$, 次いで手術のみが 11 名 $(16.9 \%)$ となって いる，受診者では手術と放射線療法が 44 名（84.6\%），

手術のみが 7 名 (13.5\%) と続いている. 診断別の比率 は返信者および受診者においても有意な差は認められな かった。

図 6 は残存歯数別にみた被験者数の分布である. 調查 対象において 0 歯残存が 33 名 (36.7\%)， 6 歯残存が 12
名 $(13.3 \%), 7$ 歯残存が 7 名 $(10.7 \%)$ となっており， 返信者では 0 歯残存が 22 名 $(33.8 \%), 6$ 歯残存が 8 名 (12.2\%)， 7 歯残存が 7 名 (10.7\%) となっていた. 受 診者では 0 歯残存が 17 名 $(32.5 \%) ， 1$ 歯残存と6 歯残 存が 6 名 (11.5\%) となっていた. 調査対象と返信者群 および受診者群ではほぼ同じ傾向がうかがわれ，返信者 および受診者とも補緅処置患者全体をあらわしていた。

図 7 は対合歯別にみた被験者数の分布である. 調査対 象では全部床義歯が 32 名 (35.6\%) と多く，次いで天 然歯列が 30 名 (33.3\%), 部分床義歯 28 名 (31.1\%), 返信者では部分床義歯が 25 名 (35.8\%), 天然歯列 22 名 (33.8\%)，全部床義歯 18 名 (27.7\%) と続いていた. 受診者では部分床義歯が 20 名 (38.5\%), 天然歯列が 18 名 $(34.6 \%)$, 全部床義歯 14 名 $(26.9 \%)$ となってお り, 調査対象と返信者群と受診者群のそれぞれにおいて 対合歯列が変化していたが，返信者群と受診者群とも有 意な差が出る程ではなかった.

図 8 は歯牙欠損様式別にみた被験者数の分布である. 調査対象では全部床義歯 33 名 (36.7\%), 両側性前蒾臼 歯遊離端義歯 20 名 $(22.2 \%) ， 一$ 側性前歯臼歯遊離義歯 15 名 (16.7\%) の順となっている. 返信者では全部床義 歯が 22 名 $(33.8 \%)$ ，両側性前歯臼遴遊離端義歯 20 名 $(30.8 \%)$ ，一側性前歯臼歯遊離端義歯 9 名 $(13.8 \%)$ と 


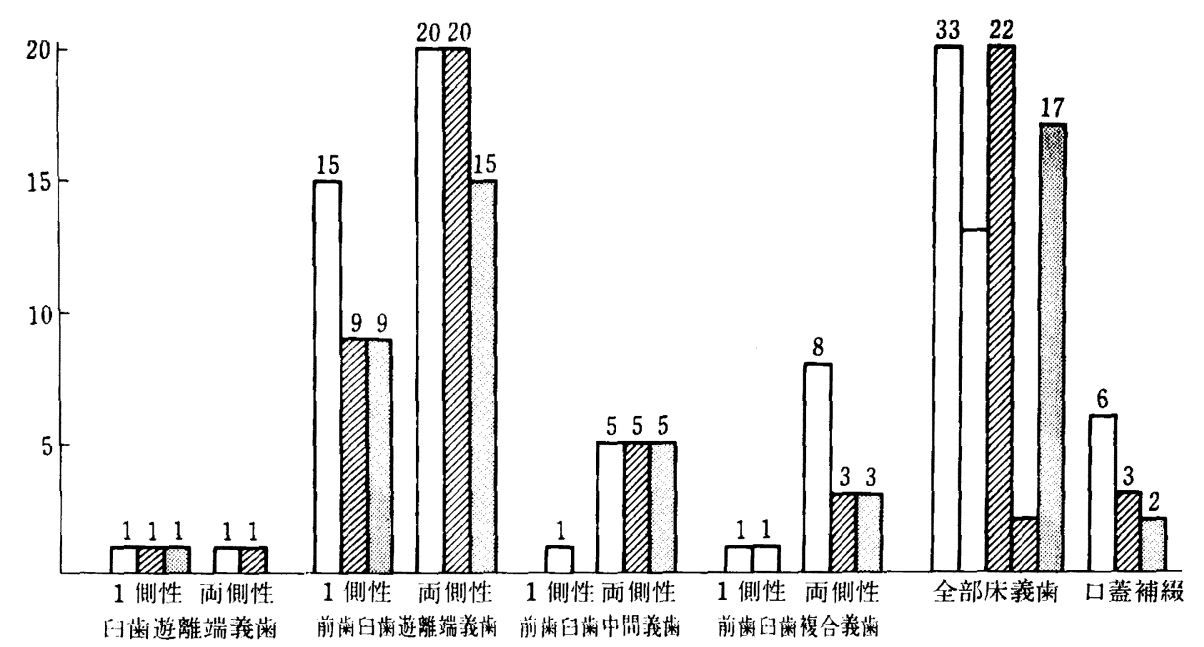

（注11）这信者群: $\mathrm{X}^{2}=5.905$

受搒者群: $\mathrm{X}^{2}=5.915$

図 8 菌牙欠損様式別にみた被験者数の分布

表 5 顎欠損形態別にみた被験者数

\begin{tabular}{|c|c|c|c|c|}
\hline \multicolumn{2}{|c|}{ 䪽火批 } & 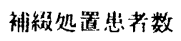 & 这信者数 & 受部者数 \\
\hline \multirow[b]{2}{*}{ 上 } & 1 & $(13.3)$ & $\begin{array}{c}8 \\
(12.3)\end{array}$ & $\left(11^{6} .5\right)$ \\
\hline & 2 & $\begin{array}{c}56 \\
(62.2)\end{array}$ & $\begin{array}{c}35 \\
(53.8)\end{array}$ & $\begin{array}{c}28 \\
(53.8)\end{array}$ \\
\hline \multirow[t]{2}{*}{ 맘 } & 3 & $\begin{array}{c}15 \\
(16.7)\end{array}$ & $\begin{array}{c}15 \\
(23.1)\end{array}$ & $\begin{array}{c}15 \\
(28.8)\end{array}$ \\
\hline & 4 & $\begin{array}{c}1 \\
(1.1)\end{array}$ & $\begin{array}{c}1 \\
(1.5)\end{array}$ & $\begin{array}{c}1 \\
(1.9)\end{array}$ \\
\hline \multirow{3}{*}{ 跑页 } & 1 & $\begin{array}{c}6 \\
(6.7) \\
\end{array}$ & $\begin{array}{c}6 \\
(9.2)\end{array}$ & $\begin{array}{c}2 \\
(3.8)\end{array}$ \\
\hline & 2 & $\left(\begin{array}{c}0 \\
(0.0)\end{array}\right.$ & $\left(\begin{array}{c}0 \\
0.0\end{array}\right)$ & $\left(\begin{array}{c}0 \\
(0.0)\end{array}\right.$ \\
\hline & 3 & $\begin{array}{c}0 \\
(0.0)\end{array}$ & $\begin{array}{c}0 \\
(0.0)\end{array}$ & $\begin{array}{c}0 \\
(0.0)\end{array}$ \\
\hline \multicolumn{2}{|c|}{ 計 } & $\begin{array}{c}90 \\
(1000.0)\end{array}$ & $\begin{array}{c}65 \\
(100.0)\end{array}$ & $\begin{array}{c}52 \\
(100.0)\end{array}$ \\
\hline
\end{tabular}

（注12）返信者群: $\mathrm{X}^{2}=3.135$ 受䧐者群: $\mathrm{X}^{2}=6.269$

なっている，受診者においては全部床義歯 17 名（32.7 $\%)$, 両側性前歯臼歯遊離端義歯 15 名 (28.8\%)，一側 性前歯且蒾遊離端義菌 9 名 (17.3\%) とほぼ同じ傾向が うかがえ，対象全体における歯牙欠損様式別の比率は返 信者および受診者においても変化は認められなかった.

表 5 は顎欠損形態別にみた被験者数をあらわしてい る. 分類は上顎では小林ら2)の分類を参考にし, 上䫑 I 級は顎堤の欠損を伴わないもの，上頇 I級は久損が顎堤
と硬口蓋に限局しているもの，上顎而級は欠損が䫑堤か

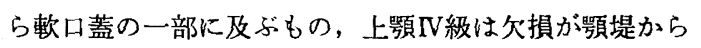
軟口藍の大きな部分に及ぶものとした.

下顎の分類としては小林ら 2) の分類を用い, 下頡 I 級 は実質欠損があっても, 左右断絶せず下頻骨体が1つに つながっているもの，下顎而級は顎の中閒部分が如し て, 顎が左右の 2 片に分離しているもの，上顎亚級は左 右何れかの一方が如しているものとした.

調查対象では上䫛 I級が 56 名 $(62.2 \%)$ と最も多く， 次いで上顎 III 級 15 名 $(16.7 \%)$, 上顎 I 級 12 名 (13.3 \%) と続いている.これに対して返信者では上䪽 II級 35 名 $(53.8 \%)$, 上䪽 III級 15 名 $(23.1 \%)$, 上頜 I 級 8 名 $(12.3 \%)$ であった．受診者では上顎 I級 28 名 (53.8 $\%)$, 上頡 III級 15 名 $(28.8 \%)$ ，上舒 I 級 6 名 $(11.5 \%)$ であった，下顎】級は全体の 1 割にも満たなかった. 対 象全体における顎欠損の比率は返信者群および受診者群 においてもほとんど変化は認められなかった.

表 6 は顔面欠損のある被験者数を示している. 顔面ま

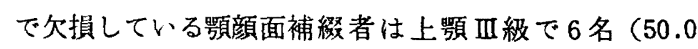
$\%)$ ，上頡I級 5 名 $(41.7 \%)$ ，下影 I 級 1 名 $(8.3 \%)$ になっていた.これらの患者の顔面欠損は眼球摘出およ び㛲部せん孔で，顎欠損が大きい程顔面にまで及ぶこと がわかる.

図 9 は手術から装着までの期間別にみた被験者数の分 布である. 調查対象では 3 カ月〜 6 力月の期間が 27 名 $(35.0 \%), 0 \sim 3$ 力月が 13 名 $(16.9 \%)$ と続き，6力月 $\sim 9$ カ月と 5 年以上が 8 名 $(10.4 \%)$ の順となってい 
た. 返信者では 3 力月〜 6 力月が最も多く 14 名 $(24.6$ $\%), 0 \sim 3$ 力月 10 名 $(17.4 \%), 6$ 力月〜 9 力月 8 名 (14.0\%) となっていた. 受診者では 3 カ月〜 6 力月が 12 名 $(26.7 \%) ， 0 \sim 3$ 力月 7 名 $(15.6 \%) ， 6$ 力月 9 力 月と 9 カ月〜12 カ月 6 名 (13.3\%) の順となっていた. 対象全体における手術から装着までの比率は返信者群お よび受診者群においてもほとんど変化は認められなかっ た.

図 10 は使用期間別にみた被験者数の分布である. 返

表 6 顔面欠損形態別にみた被験者数

\begin{tabular}{|c|c|c|}
\hline 額 & 抧 & 補綴処置患者数 \\
\hline \multirow{4}{*}{$\begin{array}{l}\text { 上 } \\
\text { 歌 }\end{array}$} & 1 & 0 \\
\hline & 2 & $5(41.7)$ \\
\hline & 3 & $6(50.0)$ \\
\hline & 4 & 0 \\
\hline \multirow{3}{*}{$\begin{array}{l}\text { 下 } \\
\text { 願 }\end{array}$} & 1 & $1(8.3)$ \\
\hline & 2 & 0 \\
\hline & 3 & 0 \\
\hline \multicolumn{2}{|c|}{ 㖕 } & $12(100.0)$ \\
\hline
\end{tabular}

（）内数字は\%

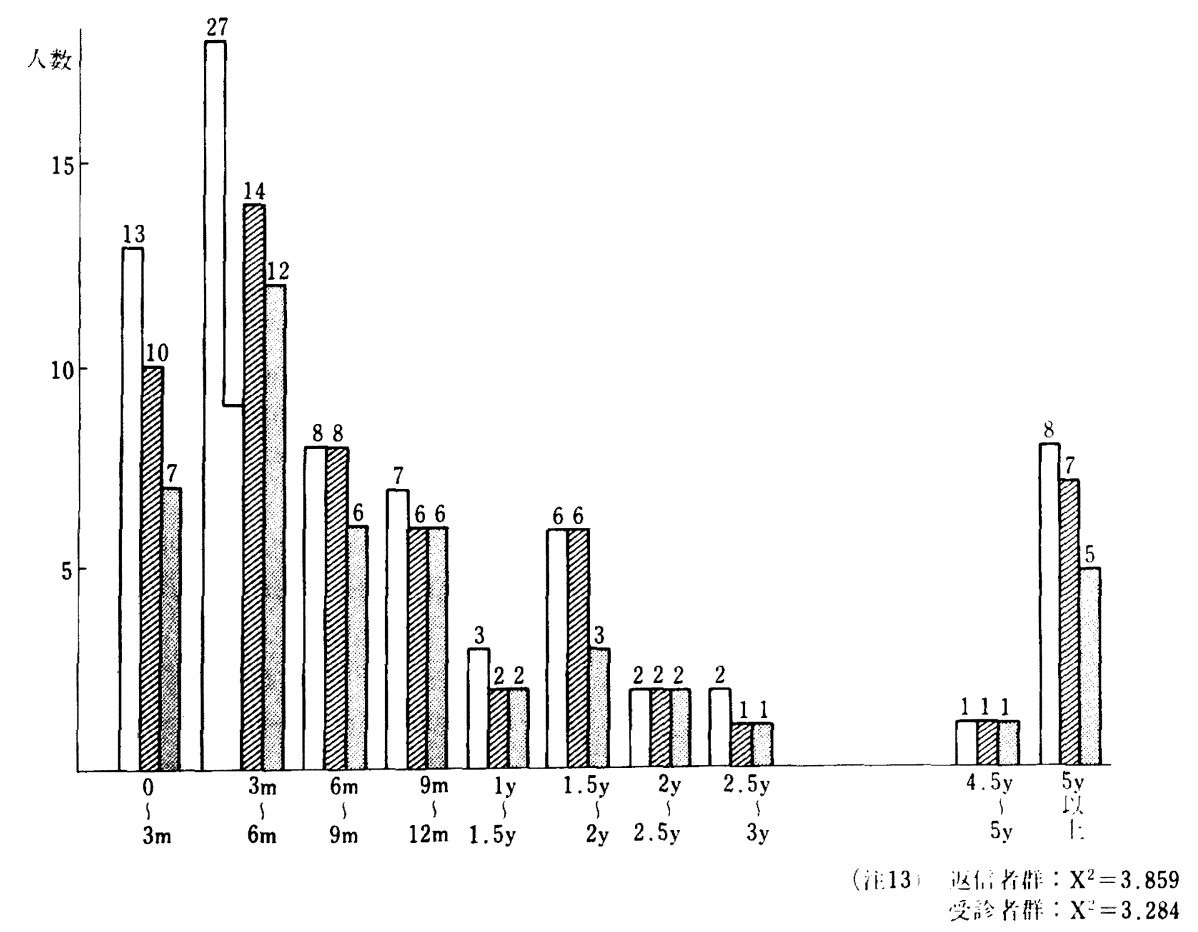

図 9 手術から装着までの期間別にみた被験者数の分师

信者においてては 0 6 6 月が 15 名 $(30.6 \%) ， 7$ 力月〜12 カ月 6 名 (12.2\%) の順となっていた. 受㟝者におい ては 0 6 6月が 15 名 $(32.6 \%), 7$ 力 12 カ月 6 名 $(13.0 \%) ， 4$ 年〜 4,5 年が 5 名 $(10.9 \%)$ であった。 ま た返信者と受診者との間には $5 \%$ のカイ検定では有意な 差はなかった。

表 7 は義蒾使用経験の有無別にみた被験者数である. 返信者で義雬使用経験のあった者 27 名 (41.5\%)，無い 者 38 名（58.5\%)，受診者ではあった者 23 名（44.2\%， 無い者 29 名 (55.8\%) とほぼ同様の傾向を示した．返 信者と受診者との間には有意な差はなかった。

\section{IV． 総括と結論}

頡補綴物装着者についての統計的調查と頡補綴義歯の 使用状態を調べるために，昭和 42 年 10 月より昭和 50 年 4 月まで東北大学歯学部附属病院補緅科に来院した 97名（内不治療 7 名）について效義歯の追跡調查を試み た. 調查方法としてアンケートと診査を併用した. アン ケートについては回答の信頼度に問題があるとされてい るので, アンケートと診查の両方に応じた症例について アンケートの回答が診査所見にどの程度一致するかを検 


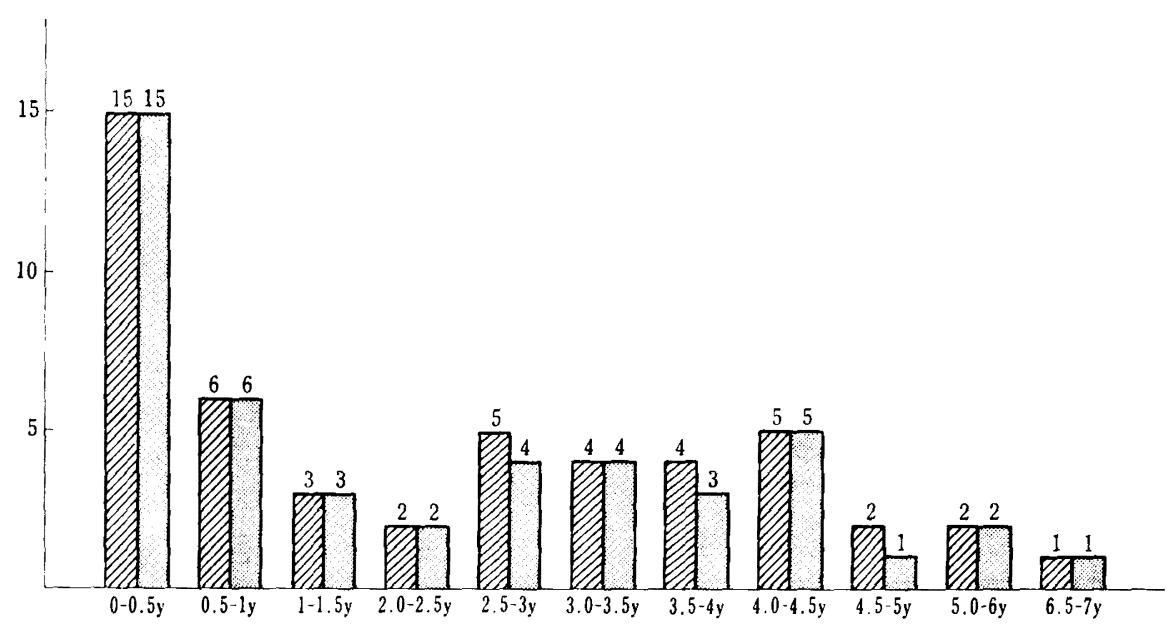

（注14）受㖣者群 $\mathrm{x}^{2}=13.327$

図 10 使用期間別にみた被験者数の分布

表 7 義药使用経験の有無別にみた被験者数

\begin{tabular}{|c|c|c|c|}
\hline & 補程処置患者数 & 返誝考数 & 受影者数 \\
\hline $\begin{array}{c}\text { 義㐘傎用䋂颗 } \\
\text { 有 }\end{array}$ & $\begin{array}{c}29 \\
(42.6) \\
\end{array}$ & $\begin{array}{c}27 \\
(41.5) \\
\end{array}$ & $\begin{array}{c}23 \\
(44.2) \\
\end{array}$ \\
\hline \multirow[t]{2}{*}{$\begin{array}{c}\text { 㼁䛧使用経糍 } \\
\text { 無 }\end{array}$} & $\begin{array}{c}39 \\
(57.4)\end{array}$ & $\begin{array}{c}38 \\
(58.5)\end{array}$ & $\begin{array}{c}29 \\
(55.8)\end{array}$ \\
\hline & $\begin{array}{c}68 \\
(100.0)\end{array}$ & $\begin{array}{c}65 \\
(100.0)\end{array}$ & $\begin{array}{c}52 \\
(100.0)\end{array}$ \\
\hline
\end{tabular}

（注15）逐信考群: $\mathrm{X}^{2}=0.719$

受衫者群: $X^{2}=0.175$

討した. アンケートのみで診査に応じなかった症例につ いてはアンケートの不備な点を電話ないし往復はがきの 調査によっておぎなった.

その結果義迷の使用の有無を問うような単純な質問に 対してはほとんど誤りが認められなかったが, 顎義歯や 口腔のこまかい変化を問う質問に対して相当数の誤りが 認められた. このようにアンケートの信頼度は質問の内 容によって著しく異なることがわかった.

調査対象のうちアンケートに応じたのは $72.2 \%$ であ り，診査を受けたのは $57.8 \%$ であった.この百分率は 他の有床義歯の調査とくに K.K. Koivumaa らの $90 \%$ 台の診查率 ${ }^{3,4,5)}$ と比べると低率であるといわざるをえな い. それは顎補綴物の特殊性と考えられる. 死亡者が $22.2 \%$ と約 4 人に 1 人の高率であることが大きな原因 であろう.また K.K. Koivumaa らは義歯装着後 1 年 ないし 2 年経過した症例を対象として調查しているのに 対し，この調查は 7 年以上経過した症例も対象としてい
ることもあり，使用期間が長い症例が多いことも全体の 百分率を低下させる一因であると考えられる.

しかし他の有床義㐘の経過観察6,7,8) と比較すると，ア ンケート返信率 $72.2 \%$ と受診率 $57.8 \%$ は高率である. これは顎補緅患者自身の住居地が遠隔地ならびその他不 利な条件にもかかわらず, 手術後の定期的な経過観察の 為医学部附属病院ならび歯学部附属病院口腔外科に来院 寸るため, 補緅科外来に受診しやすい環境にあったため と思われる.

診査に応じた症例は調査対象全体の半数をやや上回る にすぎなかったが，特定の症例だけが診查に応じたとは 考えられない，それは診査に応じた症例の各調査項目に ついての分布を, 調査対象者全体のものと比較しても差 異が認められなかったためである. 被験者の概要につい ての調查項目は, 從来通常の部分床義歯について行われ ているものに, 顎補緅物の特殊性を考えて次のむのとし た.

症例の男女別, 年齡別, 職業別, 上下顎別, 主訴別, 診断別, 治療内容別, 残存歯数別, 対合歯数別, 歯牙欠 損様式別, 影欠損様式別, 手術から装着までの期間別, 使用期間別, 義歯使用経験の有無別である.

その結果の大要は次のとおりである.

1. 来院者数の内 7 名は不治療であった. その理由は 高度の開口不全, 創傷治瘜不全, 再発および遠隔地によ る通院困難等であった。

2.上下枵別にみると大部分が上顎で，下䫛は約 $5 \%$ であった. 
3. 主訴別では咀㽉、談話障害が非常に多く，審美障 害は比較的少なかった.

4. 診断別では腫瘍が最も多く $85 \%$ 以上を占め, 唇 頻口蓋裂が約 $5 \%$ であった。

5. 残存菌数別では残存歯数 0 が $36.7 \%$ を占めてい たが，6歯残存が $13.3 \% ， 7$ 歯残存が $10.7 \%$ を示して いた.これは疾病前の残存歯数にもよるが，手術によっ て半側の穎を切除する事が多いことを示している.

6. 歯牙欠損様式別では部分床義菌が $56.7 \%$ を占め, 以下全部床義歯 $36.7 \%$ ，口蓋補緅 $6.6 \%$ を示した．部分 床義歯では前歯臼歯遊離端義歯が $68.6 \%$ を占め.

7. 顎欠損形態別では上顎 II 級が過半数を占め, 以下

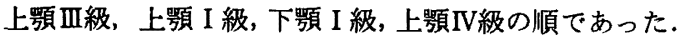

8. 手術から装着までの期間別では 1 年末満が約 $70 \%$ を占め, それ以降漸次減少していた。

\section{文献}

1）小野克己：上額切除患者の簤義雨に関する研究, 第一編 一䪽補緅物について, 京都大学口腔科学紀要, $2,71 \sim 80$, 1960.
2）小林俊三, 他：顎義歯の臨术例について(会), 補緅誌, $13: 214,1969$.

3) Koivumaa, K. K., Hedegard, B., and Carlsson, G. E. : Studies in partial dental prosthesis I, An investigation of dentogingivally supported partial dentures, Suom. hammasläah, seur. toin., $56: 249 \sim 306,1961$.

4) Carlsson, G.E., Hedegard, B., and Koivumaa, K. K. : Studies in partial dental prosthesis II. An investigation of mandibular partial dentures with double extension saddles, Acta. Odont. Scand., $19: 215 \sim 237$, 1961.

5) Carlsson, G. E., Hedegard, B., and Koivumaa, K. K. : Studies in partial dental prosthesis III, A longitudinal study of mandibular partial dentures with double extension saddles, Acta. Odont. Scand., 20 : 95 119, 1962.

6）尾花甚一,他：部分床義歯の予後に関する臨床的研究, 第 1 報 概説，補緅誌，5：207〜212，1961.

7）尾花甚一, 他：部分床義图の予後に関寸る臨床的研究 （II）第 1 報 概説, 補縔誌, $12: 146 \sim 154,1968$.

8）中沢 勇, 他：部分床義霜の予後に関する臨床的研究 （III）第 1 報 概説, 補緅誌， 19：238～246， 1975 . 